\title{
Availability and Use of Visual Teaching and Learning Materials in Teaching Geography at Nassarawa Education Zonal Office
} Ahmad Said Abubakar ${ }^{1}$,Zainab Bello ${ }^{1}$, Ali Hussain ${ }^{1}$, Nura Isyaku Bello ${ }^{2}$

\section{ARTICLE INFO}

Article History:

Received 10.10.2021

Received in revised form 04.02.2022

Accepted

Available online 01.01.2023

\begin{abstract}
The present study aimed at finding out if there are adequate visual teaching and learning mat eria ls for teaching Geography in Nasarawa Local Government Area of Kano State, and if these materials were been effectively and judiciously utilized by the teachers in teaching geography. The population of the study covers five secondary schools from five wards in Nasarawa L.G.A where a sample of 25 geography teachers both male and female was drawn. A questionnaire was used for the data collection while the data collected were analysed using the frequency and percentage distribution Table. The gathered data shown that visual materials were inadequate for the effective tea ching of geography in Nasarawa L.G.A and the few available visual materialshave not been effecti vely and judiciously utilized in teaching geography. The study has made certain recommendations that important visual materials like barometer, thermometer, rain gauge, wind vane, computers, projectors, and geography laboratory should be provided for the effective teaching and lea rning of geography, and the government should ensure that seminars and workshops are organized regularly for geography teachers to update and sensitize them of the importance of using visual materials and motivate them towards discharging their duties effectively.
\end{abstract}

CCTUARA Journal. All rights reserved

Keywords:

Geography, geography curriculum, visual material, nasarawa, Kano

\section{INTRODUCTION}

Learning is a complex process. According to Shergill (2012), learning can be defined as a change in disposition, a relatively permanent change in behavior over time and is brought about partly by experience. Learning can occur because of newly acquired skills, knowledge, perception, facts principles, and new information at hand (Adeyanju, 1997). Learning can be reinforced with different teaching and learning resources because they stimulate, motivate as well as focus the learners' attention for a while during the instructional process. Teaching and learning are facilitated in school (Sofowora and Egbedokun 2010).

Visual aids are types of designated teaching and learning materials that may be locally or commercial produced. They appeal mostly to the sense of seeing. They come in form of, for instance, wall charts, illustrated pictures, pictorial materials, and other two-dimensional objects. They can also be informed of visual and sound e.g. television, projector, and etc. which appeal to the sense of seeing and hearing. The visual aids are important teaching and learning materials that could be used to facilitate the teaching and learning of geography. Geography has been perceived as difficult and wide subject in the school curriculum, which is difficult to teach and learn. Some of the reasons put forward are the nature of the subject and the way it is being taught (Adeyanju, 1997).

Sofowora and Egbedokun (2010) confirmed that geography is taught in a way that discourages open questions, inquiry and actual participation. The effect of this is that the mind and imagination of the students are closed. They claimed that the teaching and learning of geography from its inception was through verbal description of geographic features, which made the subject very abstract and quite uninteresting. They said, the undue emphasis on theoretical aspect of geography to the detriment of scientific and experimental approach has made the subject very abstract and uninteresting to the learners. This has also resulted into making the subject no longer attractive to the young learners or scholars. Perhaps, for these reasons some people have argued that geography had no divine right to be part of educational experience of young people.They advocate the exclusion of geography from the school curriculum. Robert (1996) cited by Sofawora and Egbedokun (2010) suggested that teachers should be discouraged from using didactic method of teaching to a more creative experimental learning involving project method. He added that teacher should be encouraged toward the utilization of visual teaching and learning materials.

Arundele (1965) also cited by Sofowora and Egbedokun (2010) explained that children learn in two ways orally and visually. Many students, however, learn more rapidly when oral teaching is linked with

'Department of Geography, Aminu Kano College of Islamic and Legal Studies, asa99939@gmail.com, orcid.org/0000-0001-6332-465X

2Department of Geography, Federal College of Education, Kano, zainabello88@gmailcom, orid.org/0000-0001-7526-747X

Department of Geography, Aminu Kano Collegeof Islamic and Legal Studies, aliscience75@gmail.com, orcid.org/0000-0002-3373-2414

${ }^{4}$ Department of Geography, Kano University of Science and Technology, Wudil, isyakunura@gmail.com, orcid.org/0000-0001-81 86-5839 
something they can see, touch or handle. Arundele further explained that a teacher cannot be certain that his or her verbal description will covey the correct impression especially if he/she finds it difficult to compare the things being described with those things the students are already familiar with. He suggested that such difficulty could be removed if meditated instructions are available. Improper utilization of visual teaching and learning materials and or their total exclusion during geography lessons has come negative consequences on students' performance during geography examination. Undocumented reports from examination supervisors have it that most students or candidate of geography examination apparently avoid topographical maps, which they simply fold and keep in their pocket without attempting the question. As such, students fail the examination because the topographical maps questions take a substantial amount of marks out of the total marks of the entire geography examination. Obviously, in the light of this, it is either the students have no knowledge or have not seen a topographical map in their entire school life. In (2007), West African Examination Council (WAEC examiner's report) indicated that in geography examination, the performance of the candidates was poor and that their weaknesses were manifested in areas of map reading. The report stated that most candidates could not identify simple features on topographical map due to poor knowledge of maps and were poor in description of relief and settlement. This demonstrated clearly that there was negligence in the application of visual teaching and learning materials in the teaching and learning of geography at the secondary school level. Today, students transiting from junior secondary school (JSS) to senior secondary school (SSS) came with the fear of geography in mind. They called it geography "mugun ciwo" meaning a very difficult and unlovely subject. They prefer, according to the students, other non-vague, non-abstract, non-complex, and simple subjects than geography. This has further proven the assertion of Sofowora and Egbedokun (2010) that geography was taught in an archaic way that makes the subject despite its relationship with physical features that requires the application of visual teaching and learning materials. As such, students are discouraged to learning the subject affectively. In this light, the importance of visual teaching and learning materials which according to Dele (1963), were materials that only a concrete basis for conceptual thinking and hence reduced meaningless verbal responses from students but also help in making learning performance cannot be overemphasized.

\section{Types of Visual Materials for Teaching Geography}

The following media can be selected for utilisation in the teaching of geography.

1. World Globe: this can be used to teach topics such as the earth's spherical shape, latitude and longitude, global and water distribution, world continents, location of places on the globe, rotation of the earth etc.

2. Maps: they are types of atlas, topographical maps, and aerial photographs etc. They are mostly used for map reading and interpretation.

3. Models: these are three-dimensional media that show the length, breath and height of the object. They are used to teach physical features or reliefs. They can also be used to mould features such as conical hills, knoll, valley, spur, plateau, etc. in map work practical.

4. Charts, Diagrams and Pictures: these are two-dimensional media that represent a complete description of phenomenon or place.

5. Realia/ Real Objects: the geography teacher can use mineral resources samples such as: rocks samples, soil samples, etc.

6. Metrological Instruments: these are common weather instruments that the geographers used to measure certain climatic elements viz; rain gauge, thermometer, wind vane, anemometer, Pyrometer, dynamometer, barometer, and hygrometer for rainfall.

7. Projected Media: these are media that use source of power for generating them. They include head projector (OHP), Slide projector, Opaque projector and computer power point.

8. Chalkboard: this may be fixed, removable or portable ones. The fixed or movable ones are usually found in a typical classroom. It is very good for illustrations.

9. Printed media: such as textbooks, magazines, periodical reports, paper cuttings can be utilized by both teachers and learners in the teaching of geography.

In a latest development, according to Sofowora and Egbedokun (2010), "the Computer Assisted Instruction (CAI) has been found to be very effective in expressing geographical data, Cartography, remote sensing, simulation of geographical system, population forecasting and other geographical information systems. Today, automated and digital maps have replaced the traditional maps." 
The senior secondary school one (SSS1) geography curriculum (1985 vol. 6) had suggested that the following visual materials as effective for teaching the following topics in geography:

Table 1:Main Topics in Geography and Relevant Teaching Aids

\begin{tabular}{ll}
\hline TOPICS & VISUAL TEACHING AIDS \\
\hline Distribution of minerals and power resources & Specimens, economic map of Nigeria, map of \\
& Nigeria. \\
Population & Outline maps, population maps. \\
Physical settings of Nigeria & Sketches, diagrams, physical map of Nigeria \\
Drawing a map of the school compound & Compass, colour, blank maps, ruler \\
Conventional symbols & Models, blank maps, topography maps \\
Direction and Bearing & Models, compass maps and plans \\
\hline
\end{tabular}

\section{Problem}

Geography is one of the most important fields of knowledge that helps in understanding of the physical surrounding as well as human development. However, the teaching and learning of geography is married with a number that consequently lead to students' failure or poor performance in geography examination. Some students tend to avoid geography during their studies due to its non-motivational aspects as a result approaches or method adopted by geography teachers.

\section{Objectives}

The research investigates the availability and utilization of visual teaching and learning materials for teaching of geography through the following objectives, to:

-Identify the adequacy of visual teaching and learning materials for teaching and learning of geography.

-Determine if the visual teaching and learning materials are effectively utilized by the teachers in teaching geography.

\section{Materials and Methods}

The research design employed for this study was a descriptive survey. This design was considered appropriate for the study because it is the one which primary goal is to assess a sample at one specific point in time without trying to make inferences or casual statement. The Wales, J. (1966) defined descriptive design as a particular type of research design, which is used to describe characteristics of a population or phenomenon being studied. It is also a method used when gathering large-scale data in order to make generalization and to generate context free data. Therefore, the descriptive survey design was selected for this study because the data collected was used to describe the present situation with regards to the problems under investigation.

\section{Research Population, Sample and Sampling Techniques}

The population of the study covers all the geography teachers in Nasarawa LGA. According to statistical report obtained from the Kano State Senior Secondary School Management Board (July, 2019), the Nasarawa Education Zone. Also, there are fifty-eight secondary schools within the Zone with forty-seven geography teachers from fifty-eight secondary schools in the Zone. The geography teachers in the Zone comprised of male and female with different educational background ranging from N.C.E, B.A. Ed., B.Sc. and Postgraduate.On the other hand, five secondary schools from each cluster which made 25 sample of schools. Similarly, one head of Geography Unit in each 25 secondary schools were taken as sample. However, sampling technique employed for this research is cluster where all the secondary schools where divided into five cluster based on the proximity and using random sampling five secondary school were sampled from each cluster making twenty five (25) samples. Additionally, non-proportional sampling technique was used in taking sample of teachers; i.e. one teacher was selected from each secondary schools.

\section{Data Analysis}

The procedure for data analysis employed by the researchers was frequency and percentage distribution Table. Katzer et al (1998) cited by Milad (2013) defined frequency distribution as "a table that shows how frequently each value of the variable occurs in a set of score". Percentage distribution, according to Shapiro (1998) "is a display of data that specifies the percentage of observations that exists for each data point or grouping of data points. It is a useful method of expressing the relative frequency of survey response and other data". The process of creating a percentage frequency according to Shapiro (1998) involves dividing the frequency by the total observations and then, multiplying the result by hundred. The result was 
compiled based on cluster. That is to say each five secondary schools were compiled into one cluster. The analysis would be on five cluster based on the compiled of 5 secondary schools into one cluster.

\section{Results}

This heading analysed and discussed the results of the questionnaires administered on the research subjects. The responses on the questionnaires were presented using frequency and percentage distribution tables. The analysis and discussion were also made side by side with the data presented in each table. A total of twentyfive questionnaires were administered on the research subjects and all copies were successfully retrieved from the respondents.

\section{Summary of Data}

Table 2: Class taken by teachers

\begin{tabular}{lll}
\hline Response & Frequency & percentage \\
\hline SSS1 & 11 & 44 \\
SSS2 & 6 & 24 \\
SSS3 & 8 & 32 \\
Total & $\mathbf{2 5}$ & $\mathbf{1 0 0}$ \\
\hline
\end{tabular}

The table above indicates that (44\%) respondents teach in SSS1, (24\%) respondents teach in SSS2 and (32\%) respondents teach in SSS3 classes.

Table 3: Number of periods taken per week

\begin{tabular}{lll}
\hline Response & Frequency & Percentage \\
\hline 8 periods & 6 & 24 \\
12 periods & 10 & 40 \\
16 periods & 5 & 20 \\
24 periods & 4 & 16 \\
Total & $\mathbf{2 5}$ & $\mathbf{1 0 0}$ \\
\hline
\end{tabular}

The table above shows that (24\%) respondents had 8 periods per week, $(40 \%)$ respondents had 12 periods per week, $(20 \%)$ respondents had 16 periods per week and $(16 \%)$ respondents had 24 periods per week.

Table 4: Academic Qualification

\begin{tabular}{lll}
\hline Response & Frequency & percentage \\
\hline NCE & 10 & 40 \\
B.A/B.Sc. (Ed.) geography & 7 & 28 \\
B.Sc. geography & 5 & 20 \\
Postgraduate & 3 & 12 \\
Total & $\mathbf{2 5}$ & $\mathbf{1 0 0}$ \\
\hline
\end{tabular}

The table above indicates that $(40 \%)$ of the respondents were NCE holders, $(28 \%)$ of the respondents were B.A. (Ed) geography graduates, $(20 \%)$ of the respondents were B.Sc. geography graduates and $(12 \%)$ of the respondents were post-graduate degree holders.

Table 5: Years of teaching experience

\begin{tabular}{lll}
\hline Response & Frequency & percentage \\
\hline 3 years & 7 & 28 \\
6 years & 10 & 40 \\
10 years & 4 & 16 \\
12 years & 1 & 4 \\
27 years & 3 & 12 \\
Total & $\mathbf{2 5}$ & $\mathbf{1 0 0}$ \\
\hline
\end{tabular}

The table above indicates that $(28 \%)$ of the respondents had 3 years of teaching experience, $(40 \%)$ of the respondents had 6 years of teaching experience, $(16 \%)$ of the respondents had 10 years of teaching experience, $(4 \%)$ of the respondents had 12 years of teaching experience and $(12 \%)$ respondents had 27 years of teaching experience.

\section{Data Analysis}


Table 6: Availability of Visual Resources

\begin{tabular}{|c|c|c|c|c|c|c|c|}
\hline \multirow[b]{2}{*}{$\mathbf{S} / \mathbf{N}$} & \multirow[b]{2}{*}{ Types of Visual Resources } & \multicolumn{2}{|c|}{ YES } & \multicolumn{2}{|c|}{$\mathrm{NO}$} & \multicolumn{2}{|c|}{ TOTAL } \\
\hline & & $\mathbf{F}$ & $\%$ & $\mathbf{f}$ & $\%$ & $\mathbf{f}$ & $\%$ \\
\hline 1 & Pictures & 24 & 96 & 1 & 4 & 25 & 100 \\
\hline 2 & Economic map & 19 & 76 & 6 & 17 & 25 & 100 \\
\hline 3 & Outline map & 19 & 76 & 3 & 12 & 22 & 88 \\
\hline 4 & Population map & 17 & 68 & 5 & 20 & 22 & 88 \\
\hline 5 & Atlas map & 17 & 68 & 7 & 28 & 24 & 96 \\
\hline 6 & Contour map & 15 & 60 & 10 & 40 & 25 & 100 \\
\hline 7 & Climate \& Veg. Map & 19 & 76 & 4 & 16 & 23 & 92 \\
\hline 8 & Map of Nigeria & 24 & 96 & 1 & 4 & 25 & 100 \\
\hline 9 & Temperature map & 12 & 8 & 12 & 48 & 14 & 56 \\
\hline 10 & Ordinance survey map & 6 & 24 & 17 & 68 & 23 & 92 \\
\hline 11 & Topography map & 16 & 64 & 7 & 28 & 23 & 92 \\
\hline 12 & Compass map \& plan & 10 & 40 & 15 & 60 & 25 & 100 \\
\hline 13 & Political map & 12 & 48 & 13 & 52 & 25 & 100 \\
\hline 14 & Relative humidity map & 10 & 40 & 14 & 56 & 24 & 96 \\
\hline 15 & Relative humidity chart & 16 & 64 & 7 & 28 & 23 & 92 \\
\hline 16 & Rainfall chart & 16 & 64 & 8 & 32 & 24 & 96 \\
\hline 17 & Pie chart & 18 & 72 & 7 & 28 & 25 & 100 \\
\hline 18 & Weather symbols & 15 & 60 & 10 & 40 & 25 & 100 \\
\hline 19 & Chart of weather symbols & 6 & 24 & 16 & 64 & 18 & 72 \\
\hline 20 & Soil profile chart & 15 & 60 & 7 & 28 & 22 & 88 \\
\hline 21 & Romer and Grid Reference & 5 & 20 & 18 & 72 & 23 & 92 \\
\hline 22 & Models & 10 & 40 & 13 & 52 & 23 & 92 \\
\hline 23 & Rain gauge & 14 & 56 & 10 & 40 & 24 & 96 \\
\hline 24 & Wind vane & 15 & 60 & 7 & 28 & 22 & 88 \\
\hline 25 & Hemispherical anemometer cup & 10 & 40 & 13 & 52 & 23 & 92 \\
\hline 26 & Hygrometer & 10 & 40 & 15 & 60 & 25 & 100 \\
\hline 27 & Sling psychrometer & 5 & 20 & 17 & 68 & 22 & 88 \\
\hline 28 & Thermometer & 19 & 76 & 4 & 16 & 23 & 92 \\
\hline 29 & Barometer & 14 & 56 & 9 & 36 & 23 & 92 \\
\hline 30 & Pyranometer & 9 & 36 & 12 & 48 & 21 & 84 \\
\hline 31 & Textbooks & 25 & 100 & 0 & 0 & 25 & 100 \\
\hline 32 & Computer & 17 & 68 & 5 & 20 & 22 & 88 \\
\hline 33 & Projector & 11 & 44 & 13 & 52 & 24 & 96 \\
\hline 34 & Television and video & 10 & 40 & 14 & 56 & 24 & 96 \\
\hline 35 & Globe & 9 & 36 & 5 & 20 & 14 & 56 \\
\hline
\end{tabular}

From the table above, the availability of visual materials for the teaching of geography were indicated as follows: 25 (100\%) respondents indicated they had text books, 24 (96\%) respondents indicated they had pictures and map of Nigeria each, 19 (76\%) respondents indicated they had economic map, outline map, climate and vegetation map and thermometers each, $18(72 \%)$ respondents indicated they had pie charts, $17(68 \%)$ respondents indicated they had population map, atlas map and computers each, $16(64 \%)$ respondents indicated they had topography maps, relative humidity chart and rainfall chart each, 15 (60\%) respondents indicated they had contour maps, weather symbols, soil profile charts and wind vanes each, 14 (56\%) respondents indicated they had rain gauges and barometers each, $12(48 \%)$ respondents indicated that they had temperature maps and political maps each, 11 (44\%) respondents indicated that they had projector, $10(40 \%)$ respondents indicated that they had compass map and plan, relative humidity map, models, 
hemispherical anemometer, hygrometer and television \& video each, $9(36 \%)$ respondents indicated that they had pyranometer and globe each, 6 (24\%) respondents indicated that they had ordinance survey maps and chart of weather symbols each and $5(20 \%)$ respondents indicated that they had romer and grid reference and sling psychrometers each.

Table 7: Utilization of available visual resources

\begin{tabular}{|c|c|c|c|c|c|c|c|c|c|c|c|}
\hline \multirow[b]{2}{*}{$\mathrm{S} / \mathrm{N}$} & \multirow[t]{2}{*}{ Visual Resources } & \multicolumn{2}{|c|}{ Often } & \multicolumn{2}{|c|}{ Very often } & \multicolumn{2}{|c|}{ Sometimes } & \multicolumn{2}{|c|}{ Not at all } & \multicolumn{2}{|c|}{ Total } \\
\hline & & $\mathrm{f}$ & $\%$ & $\mathrm{f}$ & $\%$ & $\mathrm{f}$ & $\%$ & $\mathbf{f}$ & $\%$ & $\mathbf{f}$ & $\%$ \\
\hline 1 & Pictures & 8 & 32 & 1 & 4 & 6 & 24 & & & 15 & 60 \\
\hline 2 & Economic map & 4 & 16 & & & 11 & 44 & 3 & 12 & 18 & 72 \\
\hline 3 & Outline map & 3 & 12 & 4 & 16 & 8 & 32 & 3 & 12 & 18 & 72 \\
\hline 4 & Population map & 3 & 12 & 3 & 12 & 12 & 48 & 1 & 4 & 19 & 76 \\
\hline 5 & Atlas map & 3 & 12 & 7 & 28 & 7 & 28 & 4 & 16 & 21 & 84 \\
\hline 6 & Contour map & 3 & 12 & 9 & 36 & 8 & 32 & 3 & 12 & 23 & 92 \\
\hline 7 & Climate \& Veg. Map & 2 & 8 & 8 & 32 & 8 & 32 & 4 & 16 & 22 & 88 \\
\hline 8 & Map of Nigeria & 2 & 8 & 10 & 40 & 6 & 24 & & & 18 & 72 \\
\hline 9 & Temperature map & 2 & 8 & 4 & 16 & 10 & 40 & 5 & 20 & 21 & 84 \\
\hline 10 & Ordinance survey map & 4 & 16 & 5 & 20 & 5 & 20 & 8 & 32 & 22 & 88 \\
\hline 11 & Topography map & & & 7 & 28 & 6 & 24 & 4 & 16 & 17 & 68 \\
\hline 12 & Compass map \& plan & 1 & 4 & & & 6 & 24 & 8 & 32 & 15 & 60 \\
\hline 13 & Political map & & & 1 & 4 & 5 & 20 & 7 & 28 & 13 & 52 \\
\hline 14 & Relative humidity map & 2 & 8 & & & 10 & 40 & 6 & 24 & 18 & 72 \\
\hline 15 & Relative humidity chart & & & 2 & 8 & 4 & 16 & 6 & 24 & 12 & 48 \\
\hline 16 & Rainfall chart & 1 & 4 & 4 & 16 & 6 & 24 & 5 & 20 & 16 & 64 \\
\hline 17 & Pie chart & & & 4 & 16 & 4 & 16 & 6 & 24 & 14 & 56 \\
\hline 18 & Weather symbols & 4 & 16 & 2 & 8 & 4 & 16 & 6 & 24 & 16 & 64 \\
\hline 19 & Chart of weather symbols & 6 & 24 & 1 & 4 & 5 & 20 & 7 & 28 & 19 & 76 \\
\hline 20 & Soil profile chart & 4 & 16 & 2 & 8 & 1 & 4 & 6 & 24 & 13 & 52 \\
\hline 21 & Romer and Grid Reference & 4 & 16 & 4 & 16 & 6 & 24 & 8 & 32 & 22 & 88 \\
\hline 22 & Models & & & & & 6 & 24 & 10 & 40 & 16 & 64 \\
\hline 23 & Rain guage & & & & & 7 & 28 & 7 & 28 & 14 & 56 \\
\hline 24 & Wind vane & 2 & 8 & 6 & 24 & 4 & 16 & 7 & 28 & 19 & 76 \\
\hline 25 & Hemispherical anemometer cup & & & & & & & 10 & 40 & 10 & 40 \\
\hline 26 & Hygrometer & & & 1 & 4 & 6 & 24 & 10 & 40 & 17 & 68 \\
\hline 27 & Sling psychrometer & & & & & 1 & 4 & 12 & 48 & 13 & 52 \\
\hline 28 & Thermometer & 3 & 12 & & & 6 & 24 & 6 & 24 & 15 & 60 \\
\hline 29 & Barometer & & & & & 3 & 12 & 8 & 32 & 12 & 48 \\
\hline 30 & Pyranometer & 1 & 4 & & & 1 & 4 & 9 & 36 & 11 & 44 \\
\hline 31 & Textbooks & & & 10 & 40 & 2 & 8 & 2 & 8 & 14 & 56 \\
\hline 32 & Computer & 4 & 16 & 7 & 28 & 5 & 20 & 3 & 12 & 19 & 76 \\
\hline 33 & Projector & 3 & 12 & 3 & 12 & 5 & 20 & 7 & 28 & 18 & 72 \\
\hline 34 & Television and video & 3 & 12 & 1 & 4 & 5 & 20 & 8 & 32 & 17 & 68 \\
\hline 35 & Globe & & & 6 & 24 & 5 & 20 & 4 & 16 & 15 & 60 \\
\hline
\end{tabular}

From the table above table, you can see how often the utilization of visual resources. Some were frequently used, some occasionally while some of the visual resources were not being used at all.

Table 8: Which body supplies the visual material? 


\begin{tabular}{lll}
\hline Response & Frequency & Percentage \\
\hline Government & 13 & 52 \\
School management & 8 & 32 \\
PTA & 4 & 16 \\
None of the above & 0 & 0 \\
Others (specify) & 0 & 0 \\
Total & $\mathbf{2 5}$ & $\mathbf{1 0 0}$ \\
\hline
\end{tabular}

The Table above indicates that 13 (52\%) respondents said the government provided the visual materials, $8(32 \%)$ respondents said it was the school management that provided the visual materials, $4(16 \%)$ respondents said it was the PTA that provided the visual materials.

Table 9: If appropriate visual materials are not available what do you do?

\begin{tabular}{lll}
\hline Response & Frequency & Percentage \\
\hline Improvise & 15 & 60 \\
Inform the school & 10 & 40 \\
Do nothing about it & 0 & 0 \\
Total & $\mathbf{2 5}$ & $\mathbf{1 0 0}$
\end{tabular}

The table above indicates that $15(60 \%)$ respondents improvised and 10(40\%) respondents informed the school management, if visual materials are not available.

Table 10: Do you have geography laboratory in your school?

\begin{tabular}{lll}
\hline Response & Frequency & Percentage \\
\hline Yes & 3 & 12 \\
No & 22 & 88 \\
Total & $\mathbf{2 5}$ & $\mathbf{1 0 0}$ \\
\hline
\end{tabular}

From the table above, 3 (12\%) respondents indicated that they had geography laboratories in their schools while 22 (88) respondents indicated that they had no geography laboratories in their schools.

Table 11: Do you take your students for field studies?

\begin{tabular}{lll}
\hline Response & Frequency & Percentage \\
\hline Yes & 18 & 72 \\
No & 7 & 28 \\
Total & $\mathbf{2 5}$ & $\mathbf{1 0 0}$ \\
\hline
\end{tabular}

From the Table above, 18(72\%) respondents do take their students for field studies and 7 (28\%) respondents do not take their students for field studies.

Table 12: Do you have a weather station/garden in the school?

\begin{tabular}{lll}
\hline Response & Frequency & Percentage \\
\hline Yes & 6 & 24 \\
No & 19 & 76 \\
Total & $\mathbf{2 5}$ & $\mathbf{1 0 0}$ \\
\hline
\end{tabular}

From the table above, 6(24\%) respondents said that they have weather station/garden in their schools and the some of the instrument that were available in these gardens were: Barometer, rain guage thermometer, wind vane, hygrometer and 19 (76\%) said they do not have weather station/garden in their schools.

Table 13: Do your school participate in any Geography activity organized by either NGOs or other association?

\begin{tabular}{lll}
\hline Response & Frequency & Percentage \\
\hline Yes & 8 & 32 \\
No & 17 & 68 \\
Total & $\mathbf{2 5}$ & $\mathbf{1 0 0}$ \\
\hline
\end{tabular}

From the Table above, $8(32 \%)$ respondents said their schools do participate in any Geography activity organized by either NGOs or other association while $17(68 \%)$ said they don't. Some of the Geography activities being participated as mentioned by the schools were: An essay writing on satellite organized by DSTV EUTELSAT, Environmental pollution and its solutions, global entrepreneurship week and Deforestation in Kano State, planting trees in our schools and home. 
The researchers, based on the analysis of the response gathered from the research subjects have discovered the following findings:

1. Visual teaching and learning materials are inadequate for the teaching of geography in Nasarawa Education Zone of Kano State.

2. The few available visual teaching and learning materials have not been effectively and judiciously utilized by the teachers to teach geography.

\section{Discussions}

Based on the analysis of responses collected from the research subjects, the researchers have discovered two major findings as answers to the research questions, which the study seeks to investigate. Firstly, visual teaching and learning materials were inadequate for teaching and learning of geography in government secondary schools in Nasarawa Local Government Area of Kano State. This discovery by the researchers has further proven the assertions made by previous researchers (Sofowora and Egbedokun, 2010) that teaching and learning of geography from its inception was through verbal descriptions of geographic features to the detriment of scientific and experimental approach, which made the subject very abstract and quite uninteresting. They decried that geography was taught in a way that discourages open questions inquiry and actual participation. The effect of this is that, the mind and imagination of the students are closed. From the response gathered and analysed, among the factors, which led to the current downturn in the teaching and learning of geography, could be directly linked to the government, which according to the National Policy on Education (2004) is responsible to provide the educational needs. The visual materials available in some of the schools were not adequately available in all the schools, some very few were totally absent. Secondly, the researchers have discovered that the few available visual materials have not been effectively and judiciously utilized by the teachers to teach geography. Only the textbook had $100 \%$ of usage by the teachers. Important visual materials like computers, television and videos, soil profile, pie chart, compass map and plan, climate and vegetation map, weather symbols e.tc have not been frequently utilized by the teachers to teach geography. This problem could be linked to teachers' lack of awareness on the advantageous features of visual materials to teaching and learning. It can also be a problem associated with the teachers' education background. Based on the response gathered and analysed by the researchers, most of the geography teachers $(40 \%)$ from the Nasarawa LGA were NCE holders, the minimum teaching qualification. According to the National Policy on Education (2004), the NCE holder is only qualified to teach at the basic level of education (primary 1-6 and JSS 1-3). In addition, the curriculum has stipulated the teaching and learning of geography to start from senior class one (SSS 1). Therefore, teachers of geography at this level are expected to be at least possess B.A (Ed.) geography degree holders. It was also gathered that most of the schools $(76 \%)$ do not have a weather station in their schools and only $32 \%$ do participate in any Geography activity. These discoveries have further buttressed the arguments made in the paragraph above, citing scholars who have argued that geography from its inception was taught through verbal descriptions of geographic features to the detriment of scientific and experimental approach.

\section{Conclusions}

From the findings of this study and in view of the limitations of the study, the research concluded that visual teaching and learning materials were inadequate for teaching geography in Nasarawa LGA zonal office. According to the research statistic, the available visual materials were not equally available and in all the school. It can also be concluded that the geography teachers have not effectively and judiciously utilized the few available visual materials. Its only geography textbook had $100 \%$ usage by the teachers as established by the research.

\section{Recommendations}

In view of the findings discovered by the researchers, the following recommendations were made:

1. Based on the inadequacy of visual materials, it is pertinent for the government and all other stakeholders to ensure that essential visual materials like computers, projector, barometer, thermometer, pyranometer, rain gauge, wind vane etc. and Geography laboratory are provided to facilitate the teaching and learning of geography.

2. Based on the ineffective and injudicious utilization of the available visual materials, the government must ensure that geography teachers are motivated to discharge their duties effectively so that the students' performance could not be thwarted as a result of the teachers' negligence. Furthermore, seminars and workshops aimed at educating the teacher on the importance and advantages of using visual materials in 
teaching and learning of geography should be organized regularly. Also, the government must ensure that teachers who are below the required teaching qualification as stipulated by the National Policy on education (2004) are given the chance to go for in-service training or further education.

3. The research was conducted within shortest time of the program couple with financial predicaments to employ research assistant as such the scope was limited to few selected schools in the study area

\section{REFERENCES}

Abdullahi, M. (1997). An introduction to media and methods. Kano: Gidan Dabino Publishers.

Aderogba, K., A., (2012). Improvising teaching and learning aids in classes of geography in Ogun State (Nigeria) senior secondary school (SSS). International Research Journal, 3 (8), 692-697

Adeyanju, T. K. (1978). Teaching literature and human values in ESL: Objectives and selection. English Language Teaching Journal, 32(2), 133-8.

Dale, E., (1963). Audio visual methods in teaching (Revised Edition). New York. The Dryden Press.

Drost, E. A. (2011). Validity and reliability in social science research. Education Research

Perspective Journal, 38 (1), 105-123.

Ebert, K. A. (1963). Behaviourism vs constructivism in the technological secondary education classroom. Retrieved from EdTech's Website: http://site.google/a/boisestate.edu/edtechtheoiries/behaviourism-vsconstructivismin-the technological-secondary-educationclassroom-1

Federal Republic of Nigeria (1981). National policy on education. Federal Government Press, Federal Republic of Nigeria.

Federal Republic of Nigeria (1985). National curriculum for senior secondary school. Federal Government Press, Federal Republic of Nigeria.

Graham, G. (2010). “Behaviourism”, In Edward Z.(Ed.). The Stanford Encyclopedia of Philosophy. Retrieved from url:http://plato.stanford.edu.archieves/fall2010/entries/behaviorism/

Instructional Design Central. (2004). Instrustructional design models. Retrieved from www.instructionaldesigncentral.com/htm/idc_instuctionaldesignmodels.htm

Krejcie, R. V. \& Morgan D. W. (1970). Determining sample size for research activities. Educational Psychology Measurement Journal, 30(3), 607-610.

Lawal, R. M., Dora, A. \& Julius, G. (2014). Secondary school students' attrition in Geography in Esan West Local Government Area, Edo State, Nigeria: The teachers perspective. Sky Journal of Education Research, 2 (4), 028-036.

McNeeley, R. S. (2007). Learning theories in early childhood classroom learning. Retrieved from www.web.utk.edu/ rmcneeleeyclassrom/theories $/ \mathrm{html}$.

Milad, A. C. (2013). Risk evaluation and mitigation in domestic photovoltaic projects according to the UK climate policy. Retrieved from http://www.google.com/m?q=katzer+percentage+milad\&client=ms-operaminiandroid\&channel=new

Okunrotifa, P. O. (1970). Programmed learning in teaching of geography. West African Journal of Education, 14 (30), 283-293.

Olowu, F. A. (2005). Educational technology: A conceptual guide. Ijebu OdeGodolom Books.

Oyesola G., O., (1991) Criteria for selecting audio-visual materials in geography teaching in post primary institution. Ilorin Journal of Education,11.

Sabitu, A. O. \& Nuradeen, B. B. (2010). Teachers' attributes as correlates of students' academic performance in geography in the secondary schools in Ondo State, Nigeria. Pakistan Journal of Social Sciences, 7, 388-392.

Shapiro, J. K. (2008). Percentage frequency distribution. Retrieved from: Sage research methods' website: http://srmosagepub.com/view/enclopedia-of-surveyresearch-methods/n372.xml

Sheriffudin, S. R. (2007). Design of instructional materials for teaching and learning purpose: Theory into practice. Malaysia Education Deans' Journal,1, 98-110

Sherigill, H., R., (2012). Experimental psychology. Delhi, PHI Learning PVT. LTD.

Sofowora, O. A. \& Egbedokun A. (2010). An empirical survey of technology application in teaching geography in Nigerian secondary schools. Ethiopian Journal of Environmental Studies and Management 3. (1), 46-54.

United Nations (2005). Millennium development goals. New York: UN Retrieved from http://www.un.org/apps/neas/story/asp? 
WAEC (2007). Chiefexaminers' report. West Africa Examinations Council.

Wales, J. (1975). The place of teaching aids in Nigerian education. West African Journal of Education, 3(2), 2329.

World Bank (2004). ICT Report. Retrieved from http://www.worldbank.org/education/pdf/ict-report-oct-04 